\title{
Effects of seasonal and latitudinal cold on oxidative stress parameters and activation of hypoxia inducible factor (HIF-1) in zoarcid fish
}

\author{
K. Heise - M. S. Estevez $\cdot$ S. Puntarulo $\cdot$ M. Galleano $~$ \\ M. Nikinmaa $\cdot$ H. O. Pörtner · D. Abele
}

Received: 25 October 2006/Revised: 23 May 2007/Accepted: 24 May 2007

(C) Springer-Verlag 2007

\begin{abstract}
Acute, short term cooling of North Sea eelpout Zoarces viviparus is associated with a reduction of tissue redox state and activation of hypoxia inducible factor (HIF1 ) in the liver. The present study explores the response of HIF-1 to seasonal cold in Zoarces viviparus, and to latitudinal cold by comparing the eurythermal North Sea fish to stenothermal Antarctic eelpout (Pachycara brachycephalum). Hypoxic signalling (HIF-1 DNA binding activity) was studied in liver of summer and winter North Sea eelpout as well as of Antarctic eelpout at habitat temperature of $0^{\circ} \mathrm{C}$ and after long-term warming to $5^{\circ} \mathrm{C}$. Biochemical parameters like tissue iron content, glutathione redox ratio, and oxidative stress indicators were analyzed to see whether the cellular redox state or reactive oxygen species formation and HIF activation in the fish correlate. HIF-1 DNA binding activity was significantly higher at cold temperature, both in the interspecific comparison, polar $v s$. temperate species, and when comparing winter and summer North Sea eelpout. Compared at the low acclimation temperatures $\left(0^{\circ} \mathrm{C}\right.$ for the polar and $6^{\circ} \mathrm{C}$
\end{abstract}

Communicated by G. Heldmaier.

K. Heise · H. O. Pörtner · D. Abele $(\bowtie)$

Alfred-Wegener-Institute for Polar and Marine Research,

Am Handelshafen 12, 27570 Bremerhaven, Germany

e-mail: Doris.Abele@awi.de

M. S. Estevez - S. Puntarulo - M. Galleano

Physical Chemistry-PRALIB,

School of Pharmacy and Biochemistry

University of Buenos Aires, Junin 956,

C 1113 AAD Buenos Aires, Argentina

M. Nikinmaa

Animal Physiology, Department of Biology,

University of Turku, 20014 Turku, Finland for the temperate eelpout) the polar fish showed lower levels of lipid peroxidation although the liver microsomal fraction turned out to be more susceptible to lipid radical formation. The level of radical scavenger, glutathione, was twofold higher in polar than in North Sea eelpout and also oxidised to over 50\%. Under both conditions of cold exposure, latitudinal cold in the Antarctic and seasonal cold in the North Sea eelpout, the glutathione redox ratio was more oxidised when compared to the warmer condition. However, oxidative damage parameters (protein carbonyls and thiobarbituric acid reactive substances (TBARS) were elevated only during seasonal cold exposure in Z. viviparus. Obviously, Antarctic eelpout are keeping oxidative defence mechanisms high enough to avoid accumulation of oxidative damage products at low habitat temperature. The paper discusses how HIF could be instrumental in cold adaptation in fish.

Keywords North Sea eelpout - Polar eelpout · HIF-1 . Oxidative stress · Glutathione

\section{Introduction}

The hypoxia inducible transcription factor 1 (HIF-1) activates an array of more than 70 target genes that support hypoxic survival and anaerobic energy production under physiological conditions, which cause severe downfall of the intracellular oxygen tension (Acker et al. 2006). HIF dependent hypoxic regulation has so far been identified in mammals, fish, invertebrates, and yeast, and a multitude of review papers summarize the complex state of present knowledge on its physiological role and regulation in different model and non-model systems (Huang and Bunn 2003; Acker and Acker 2004; Gorr et al. 2006; Fandrey 
et al. 2006; Acker et al. 2006). The molecular mechanisms involved in HIF regulation have been most thoroughly investigated in mammalian tissues and cell models. HIF is a heterodimer consisting of two basic-helix-loop-helix PAS proteins (HIF- $\alpha$ and HIF- $\beta$ ). Of both subunits, only HIF- $1 \alpha$ protein levels are regulated in an oxygen dependent manner by prolyl-hydroxylase enzymes (PHDs), whereas HIF-1ß is constitutively expressed and functional as nuclear translocator protein (ARNT). The prolyl hydroxylases target HIF$1 \alpha$ for proteasomal degradation and, hence enable its removal from the cell, by hydroxylating two characteristic proline residues within a functional region of the protein, dubbed oxygen-dependent degradation domain (ODD, Ivan et al. 2001; Fandrey et al. 2006). The hydroxylating activity of the PHDs depends on the oxygen concentration in the cell and involves iron (II), ascorbate (for iron reduction) and 8-oxoglutarate as cofactors. Proteasomal degradation of HIF- $1 \alpha$ abrogates the hypoxic response in a tissue under physiological normoxia conditions (see Wenger 2000; Huang and Bunn 2003) and the PHDs are therefore ascribed cellular oxygen sensor functions (Fandrey et al. 2006). While most studies have suggested that HIF levels are regulated via oxygen-dependent breakdown, recent studies on hypoxia-tolerant animals from different vertebrate groups suggest that also HIF mRNA levels may be regulated (Shams et al. 2004; Rissanen et al. 2006; Law et al. 2006).

Functional HIF-systems and their inducibility under hypoxia in cells and in vivo have recently been confirmed in fish (Soitamo et al. 2001; Nikinmaa and Rees 2005). A role for HIF-responses is also discussed in thermal adaptation. In insect larvae HIF- $1 \alpha$ transcripts as well as protein levels increase in response to seasonal cold exposure and freezing (Morin et al. 2005), and recent studies by Rissanen et al. (2006) and Heise et al. (2006a, b) suggested that HIF may play a role in cold tolerance in eurythermal freshwater and marine fish. Rissanen et al. (2006) exposed extremely hypoxia tolerant crucian carp to controlled cooling over several weeks and found increased HIF protein expression and/or DNA-binding activity (in band shift assays) in liver, heart, gill and kidney, which was associated with a marked increase in HSP70 and 90 levels. We have investigated the HIF response to cold shock in North Sea eelpout (Heise et al. 2006a) and found HIF-1 DNA binding in liver tissue (the only organ we investigated) significantly enhanced following $2 \mathrm{~h}$ cold exposure to 1 and $5^{\circ} \mathrm{C}$, compared to control fish kept at $12^{\circ} \mathrm{C}$. In contrast, $2 \mathrm{~h}$ of heat shock above $20^{\circ} \mathrm{C}$ failed to have an effect on eelpout HIF (Heise et al. 2006b). Based on these previous findings, we hypothesized that HIF-1 signalling could especially be involved in the physiological regulation supporting seasonal and regional cold tolerance in fish. Moreover, reports like the increase in muscle capillary density in striped bass following cold acclimation from 25 to $5^{\circ} \mathrm{C}$ (Johnston 1982; Egginton and Sidell 1989) point at a possible HIF-dependent up-regulation of vascular endothelial growth factor (VEGF) and other HIF target genes.

In the present study we have investigated the hypoxic response in eurythermal North Sea eelpout, Zoarces viviparus, and their stenothermal Antarctic counterpart, the eelpout Pachycara brachycephalum from King-George Island, South Shetland Islands, to clarify whether or not HIF plays a role in seasonal cold acclimatization in the North Sea eelpout or in adaptation to permanent cold in Antarctic waters. We measured HIF- $1 \alpha$ protein levels and DNA-binding capacity of HIF-1 in unstressed North Sea eelpout collected during winter $\left(6^{\circ} \mathrm{C}\right)$ and summer $\left(12^{\circ} \mathrm{C}\right)$. In the stenothermal Antarctic Pachycara brachycephalum the same parameters were measured close to habitat temperature $0^{\circ} \mathrm{C}\left(0-0.6^{\circ} \mathrm{C}\right.$, Brodte et al. 2006b), and upon several weeks of acclimation to $5^{\circ} \mathrm{C}$, at the warm border of the thermal tolerance range of this Antarctic fish. Severe heat stress in this species commences at $7^{\circ} \mathrm{C}$ (Mark et al. 2002a).

As several steps of the oxygen sensitive signalling cascade (stabilisation of HIF- $1 \alpha$, DNA binding activity of HIF-1) are redox controlled (Haddad et al. 2000; Nikinmaa et al. 2004) and modulated by reactive oxygen species (ROS) formation (Acker et al. 2006), we suspected that oxidative stress, but also the content of unbound free iron in the tissues could affect the HIF response (Czubryt et al. 1996; Nikinmaa 2002). Therefore a variety of cellular oxidative stress parameters (oxidative damage and antioxidant defence), the cellular redox state (GSSG:GSH) and also the levels of bound and labile iron were tested in liver tissues of both fish at warm and cold temperatures.

\section{Material and methods}

Animal collection and experimental conditions

Antarctic eelpout (Pachycara brachycephalum) were caught with bottom traps near King George Island (Maxwell Bay) at $400 \mathrm{~m}$ depth during Antarctic expedition with RV Polarstern (ANT XIX/5) in April 2002. Both fishes belong to the family of zoarcids and have a similar behaviour, mainly inactive, carnivorous sit-and-wait predators (Van Dijk et al. 1999). At the Alfred-Wegener Institute, a total of 30 animals was kept at $0^{\circ} \mathrm{C}$ in natural sea water from the North Sea with constant aeration and a day-night cycle of $12 \mathrm{~h}$ until the beginning of the acclimation experiment in December 2002. A batch of 15 polar eelpout was acclimated for 11 weeks at $5^{\circ} \mathrm{C}$. Fish were fed live mud shrimp once a week. Fishes in the control group were $43.4 \pm 12.4 \mathrm{~g}$ weight and $23.4 \pm 3.7 \mathrm{~cm}$ length and 
those in the warm acclimated group $48.4 \pm 10.6 \mathrm{~g}$ weight and $24.5 \pm 2.2 \mathrm{~cm}$ length. After 11 weeks fish were narcotised with $0.5 \mathrm{mg}$ MS222 $\mathrm{1}^{-1}$ seawater, weighed and killed by a cut through the spine. Tissue samples of the liver were quickly taken and aliquots of $100 \mathrm{mg}$ frozen in liquid nitrogen. Samples were stored at $-80^{\circ} \mathrm{C}$. After sampling, sex and length of the eelpout were determined.

Fourteen temperate eelpout, Zoarces viviparus, were caught near the island of Helgoland in the German North Sea in December 2002 (winter animals). Lowest habitat water temperatures in winter $2002 / 2003$ were about $3^{\circ} \mathrm{C}$ (sea surface temperature taken from MURSYS, Bundesamt für Seeschiffahrt und Hydrografie). Fish were fed pellets of white fish (Merlangius merlangus) once a week and kept in an aquarium with a flow-through system of natural filtered sea water, which had the same temperature as the outside water in the natural habitat. Tissues were sampled in February 2003 at a water temperature of $6^{\circ} \mathrm{C}$. Zoarces viviparus summer animals were caught in May and June 2002 and maintained at constant $12^{\circ} \mathrm{C}$ for 1 month. Winter animals had a body mass of $49.9 \pm 15.4 \mathrm{~g}$ and a length of $23.7 \pm 1.6 \mathrm{~cm}$ and summer animals weighed $54.4 \pm 31.1 \mathrm{~g}$ at a length of $22.8 \pm 3.5 \mathrm{~cm}$. All parameters were determined in liver tissue.

DNA-binding activity of the hypoxia inducible factor (HIF-1)

The DNA binding activity of HIF-1 was determined after Vuori et al. (2004), Soitamo et al. (2001), Kvietikova et al. (1995) as an indicator for hypoxic signalling. Nuclear extraction protocols, developed for rainbow trout (Soitamo et al. 2001) were not applicable to small tissue samples. Thus, electromobility shift assay (EMSA) and Western blotting were carried out with whole cell extracts (Vuori et al. 2004). Fifty milligram of liver tissues were homogenised in $200 \mu \mathrm{l}$ buffer C (25\% glycerol, $0.42 \mathrm{M} \mathrm{NaCl}$, $1.5 \mathrm{mM} \mathrm{MgCl}_{2}, 0.2 \mathrm{mM}$ EDTA, $20 \mathrm{mM}$ Hepes, $0.5 \mathrm{mM}$ PMSF, $0.5 \mathrm{mM}$ DTT, $2 \mu \mathrm{g} \mathrm{ml}^{-1}$ leupeptine, $2 \mu \mathrm{g} \mathrm{ml}^{-1}$ antipaine, $2 \mu \mathrm{g} \mathrm{ml}^{-1}$ pepstatine, $2 \mu \mathrm{g} \mathrm{ml}^{-1}$ aprotinin, $1 \mathrm{mM} \mathrm{Na} \mathrm{VO}_{4}$ ) and centrifuged at $16,100 \mathrm{~g}, 30 \mathrm{~min}, 4^{\circ} \mathrm{C}$. The supernatant was transferred to a new tube and the protein content determined by the Bio-Rad assay in a microplate reader.

For Western blotting ( $20 \mu \mathrm{g}$ protein of whole cell extracts per well) polyclonal antibodies directed against the $\mathrm{N}$-terminus of rainbow trout HIF- $1 \alpha$ were used (Soitamo et al. 2001). The antibody recognised a hypoxia-inducible protein, thus assigned as HIF- $1 \alpha$ in $Z$. viviparus, but not in $P$. brachycephalum.

Following the fish protocol of Soitamo et al. (2001), we used the promoter region of the human erythropoietin (EPO) gene as HIF-sensitive DNA probe $\left(5^{\prime}-\right.$
GCCCTACGTGCTGTCTCA-3'). $5^{\prime}$-endlabeling of the sense strand $\left(2\right.$ pmol $\mu \mathrm{l}^{-1}$ DNA) was done with $10 \mathrm{U}^{-1} \mathrm{l}^{-1}$ $\mathrm{T} 4$ polynucleotide kinase and ${ }^{32} \mathrm{P}-\gamma$-dATP $(10 \%$ v/v) over $15 \mathrm{~min}$ at $37^{\circ} \mathrm{C}$. After removing unincorporated nucleotides by purifying through a sephadex G- 25 column, probes were annealed with $2 \mathrm{pmol}_{\mu \mathrm{l}^{-1}}$ antisense strand, $5 \mathrm{mM}$ $\mathrm{MgCl}_{2}$ and TE buffer (10 mM Tris/HCl, $1 \mathrm{mM}$ EDTA, $\mathrm{pH}$ 8.0).

EMSA DNA-protein binding reactions were carried out for $30 \mathrm{~min}$ on ice in a total volume of $20 \mu \mathrm{l}$, containing $10 \mu \mathrm{g}$ cell extract, $0.1 \mu \mathrm{g} \mu \mathrm{l}^{-1}$ carrier DNA (poly dI-dC), DNA binding buffer (10 mM Tris/HCl, pH 7.5), $50 \mathrm{mM}$ $\mathrm{KCl}, 50 \mathrm{mM} \mathrm{NaCl}, 1 \mathrm{mM} \mathrm{MgCl}$, $1 \mathrm{mM}$ EDTA, $5 \mathrm{mM}$ DTT, 5\% glycerol), $1 \mu \mathrm{l}^{32} \mathrm{P}$-endlabeled DNA probe, $1 \mu \mathrm{l}$ bromphenol blue $(1.5 \%)$. Samples were run on $4 \%$ nondenaturating glycerolpolyacrylamide-gel (4\% acrylamide, $1 \%$ glycerol, TBE buffer). Electrophoresis was performed at $150 \mathrm{~V}$, room temperature, $2 \mathrm{~h}$ in TBE buffer $(89 \mathrm{mM}$ Tris, $89 \mathrm{mM}$ boric acid, $5 \mathrm{mM}$ EDTA). Dried gels were autoradiographed (Kvietikova et al. 1995). Calculation of the percentage intensity was based on densitometry of gel images, with the sum of all four bands taken as $100 \%$ value. Control experiments for testing the specificity of the human EPO enhancer by adding an excess of unlabeled probe or by adding antibody (against the N-terminus of rainbow trout HIF- $1 \alpha$, see above) are described in our previous study on Z. viviparus (Heise et al. 2006b). No antibody was available which recognised the HIF- $1 \alpha$ protein in liver samples from $P$. brachycephalum. Therefore, the supershift assay could not be carried out for the Antarctic eelpout. The specificity of the observed band has been determined in three fish species in the laboratory of M. Nikinmaa (see also Soitamo et al. 2001; Rissanen et al. 2006). Further, the signal of the complex band appeared at the same location as that found in North Sea eelpout, indicating the band to have the molecular size of the HIF-1EPO enhancer complex.

\section{Oxidative stress parameters}

Thiobarbituric reactive substances (TBARS) were determined as a marker of lipid peroxidation, indicating oxidative damage in the lipid fraction according to Uchiyama and Mihara (1978). Briefly, deep frozen tissues were ground in liquid nitrogen and homogenised in $1.1 \%$ phosphoric acid (1:10 to $1: 20$; w:v). To $400 \mu \mathrm{l}$ of homogenate the same amount $1 \%$ thiobarbituric acid (TBA, dissolved in $50 \mathrm{mM} \mathrm{NaOH}$, containing $10 \mathrm{mM}$ butylated hydroxytoluene) was added. For blanks, TBA was replaced by $3 \mathrm{mM}$ $\mathrm{HCl}$. The solutions were heated $1 \mathrm{~h}$ at $100^{\circ} \mathrm{C}$ and subsequently extracted with $2 \mathrm{ml}$ butanol by vortexing for $40 \mathrm{~s}$ and by centrifugation $(5 \mathrm{~min}$ at $1,000 \mathrm{~g}$ ). The resulting supernatant was centrifuged and the TBARS content 
spectrophotometrically determined as the difference $A_{532 \mathrm{~nm}}-A_{600 \mathrm{~nm}}$. After blank subtraction, the TBARS content was calculated using a five-point calibration curve, obtained with malondialdehyde-(bis)-acetate (MDA, Merck) standard.

Tert-butyl hydroperoxide-initiated chemiluminescence was measured according to Gonzalez Flecha et al. (1991). Chemiluminescence indicates an imbalance between proand antioxidant processes resulting from depletion of antioxidant compounds like glutathione, vitamin $\mathrm{E}$ and vitamin C. Tissue samples were homogenised in $30 \mathrm{mM}$ $\mathrm{KP}_{\mathrm{i}}$ buffer (pH 7.4) containing $120 \mathrm{mM} \mathrm{KCl}$ and centrifuged at $600 \mathrm{~g}$ for $10 \mathrm{~min}$. The supernatants were diluted in buffer, containing a final concentration of $3 \mathrm{mM}$ tert-butyl hydroperoxide and assayed in the dark at room temperature for chemiluminescence (counts per minute) in a liquid scintillation counter (Wallac, Turku, Finland) in the out-ofcoincidence mode, using potassium glass vials kept in the dark for at least $48 \mathrm{~h}$ to avoid vial phosphorescence activation by fluorescent light. The chemiluminescence data were determined as counts per minute and were expressed in a tissue specific curve with $y=$ chemiluminescence and $x=$ time. The area under this curve could be calculated for a time period of 3,600 s using the Mat Lab program. The results are expressed as arbitrary area units per microgram of protein over the studied period.

Carbonyl groups were determined as an indication of oxidative damage to proteins according to Levine et al. (1990). Samples were homogenised in $50 \mathrm{mM}$ HEPES buffer, pH 7.4, containing $125 \mathrm{mM} \mathrm{KCl}, 1.1 \mathrm{mM}$ EDTA, $0.6 \mathrm{mM} \mathrm{MgSO}_{4}$ and protease inhibitors $\left(0.5 \mathrm{mg} \mathrm{ml}^{-1}\right.$ leupeptine, $0.7 \mu \mathrm{g} \mathrm{ml}^{-1}$ pepstatine, $40 \mu \mathrm{g} \mathrm{ml}^{-1}$ phenylmethylsulfonyl fluoride, $0.5 \mu \mathrm{g} \mathrm{ml}^{-1}$ aprotinin) and centrifuged at $100,000 \mathrm{~g}$ for $15 \mathrm{~min}$. Supernatants were incubated at room temperature for $1 \mathrm{~h}$ with $10 \mathrm{mM}$ 2,4-dinitrophenylhydrazine (DNTP) in $2 \mathrm{M} \mathrm{HCl}$. Blanks were run without DNTP. Afterwards, proteins were precipitated with TCA and centrifuged for $10 \mathrm{~min}$ at $10,000 \mathrm{~g}$. The protein pellet was washed three times with ethanol:ethylacetate (1:1), resuspended in $6 \mathrm{M}$ guanidine hydrochloride in $20 \mathrm{mM}$ potassium phosphate $(\mathrm{pH}=2.3)$ and incubated at $37^{\circ} \mathrm{C}$ until complete resuspension. The carbonyl content could be measured spectrophotometrically at $360 \mathrm{~nm}$ (molar extinction coefficient $\varepsilon=22,000 \mathrm{M}^{-1} \mathrm{~cm}^{-1}$ ).

\section{Reduced (GSH) and oxidised (GSSG) glutathione measured according to Fariss and Reed (1987) and calculation of cellular redox potential}

The glutathione status represents the most important indicator of and determinant for the cellular redox environment (Schafer and Buettner 2001). Frozen tissue was ground in liquid nitrogen and the resulting powder homogenised in
1:10 (w:v) pre-cooled PCA (10\% containing $2 \mathrm{mM}$ bathophenantroline-disulphonic acid). After centrifugation at $15,000 \mathrm{~g}$ for $5 \mathrm{~min}$ at $4^{\circ} \mathrm{C}, 500 \mu \mathrm{l}$ of the supernatant were mixed with $10 \mu \mathrm{pH}$-indicator $(1 \mathrm{mM}$ m-cresol purple sodium salt containing $0.5 \mathrm{M}$ iodoacetic acid (IAA)). $50 \mu \mathrm{l}$ $1 \mathrm{mM} \gamma$-glutamyl-glutamate (in $0.3 \%$ PCA) was added as internal standard. The $\mathrm{pH}$ was adjusted to 8.5 with $5 \mathrm{M}$ $\mathrm{KOH}$ (containing $0.3 \mathrm{M} \mathrm{N}$-morpholine-propanesulfonic acid). The mixture was incubated at room temperature for $45 \mathrm{~min}$, to allow IAA to bind GSH. Subsequently, samples were centrifuged for $5 \mathrm{~min}$ at $15,000 \mathrm{~g}$ at $4^{\circ} \mathrm{C}$. $300 \mu \mathrm{l}$ of the supernatant were added to the double amount of $1 \% 1$ fluor-2,4-dinitrobenzene (diluted in 100\% ethanol, HPLC grade) and derivatised in dark vials at room temperature over $24 \mathrm{~h}$. After centrifugation at 7,500g for $1 \mathrm{~min}$ at $4^{\circ} \mathrm{C}$ and filtration through $0.2 \mu \mathrm{m}$ nylon membrane filters, samples were stored in dark HPLC vials at $-20^{\circ} \mathrm{C}$.

HPLC determination was carried out on a Beckmann Coulter HPLC System using a $\mathrm{NH}_{2}$-spherisorp column, $5 \mu \mathrm{m} 240 \times 4 \mathrm{~mm}$ (Waters, Germany). Solvent A: $80 \%$ methanol and solvent B: sodium acetate stock in $80 \%$ methanol (20:80). Sodium acetate stock was prepared by dissolving $500 \mathrm{~g}$ Na-acetate in $224 \mathrm{ml}$ Milli-Q water and $695 \mathrm{ml}$ of concentrated HPLC-grade acetic acid. The gradient programme was as follows: $10 \mathrm{~min}$ hold at $90 \% \mathrm{~A}$ followed by a 25 min linear gradient to $25 \% \mathrm{~A}$ at a flow rate of $1 \mathrm{ml} \mathrm{min}^{-1}$ and 2.3-2.8 psi backpressure. Peaks were recorded with a photodiode array detector at $365 \mathrm{~nm}$. Concentrations were calculated using five-point calibration curves for GSH and GSSG standards processed in the same manner as described for the samples.

As GSSG is formed by oxidation of two GSH molecules, total glutathione content was calculated as the sum (2 GSSG + GSH). Accordingly, the redox ratio of oxidised to reduced glutathione was expressed as $2 \mathrm{GSSG} / \mathrm{GSH}$.

The redox potential was calculated with the Nernst equation:

$\Delta E=E^{\mathrm{opH}}-(R T \times 2.303 / n F) \log ([\mathrm{GSH}] /[\mathrm{GSSG}]) \mathrm{mV}$

as given by Schafer and Buettner (2001), for the different temperatures of maintenance, also considering the temperature induced changes of intracellular $\mathrm{pH}\left(\mathrm{pH}_{\mathrm{i}}\right)$ in fish liver (values were taken from Larsen et al. 1997 and Sartoris et al. 2003).

$\alpha$-tocopherol concentration according to Desai (1984)

$\alpha$-tocopherol represents the most active compound of the lipid-soluble non-enzymatic antioxidant vitamin E (Dunlap et al. 2002). Tissue samples were homogenised with sodium dodecylsulfate (SDS). To $300 \mu \mathrm{l}$ homogenate, or $100 \mu \mathrm{l}$ of microsome suspension, $1 \mathrm{ml}$ of ethanol was ad- 
ded and vortexed for $1 \mathrm{~min}$. Then, $4 \mathrm{ml}$ of hexane were added and the mixture vortexed again for $1 \mathrm{~min}$. After 10 min centrifugation at $600 \mathrm{~g}$, the lipid phase was dried with nitrogen, resuspended in methanol:ethanol (1:1) and filtered through nylon membranes, $0.22 \mu \mathrm{m}$. Hereafter, samples were analysed by reverse phase high performance liquid chromatography (HPLC) and electrochemical detection with an oxidation potential of $0.6 \mathrm{~V}$ and a flow rate of $1 \mathrm{ml} \mathrm{min}^{-1}$. The isocratic system consisted of a column (Supelcosil LC-8, $3 \mu \mathrm{m} 15 \mathrm{~cm} \times 4.6 \mathrm{~mm}$, Supelco 58983 ) and a solvent containing $20 \mathrm{mM} \mathrm{LiClO}_{4}$ in $99 \%$ methanol.

Determination of the intracellular "free" iron by electron paramagnetic spin resonance (EPR) spectroscopy

Iron contents were measured as possible catalysts for Fenton reactions leading to enhanced formation of $\mathrm{OH}$ and consequent lipid radical formation (Halliwell and Gutteridge 1985). Tissue samples frozen in liquid nitrogen and pooled from two animals were weighed without thawing and ground to powder in a porcelain mortar. The powder obtained was mixed at ratio $1: 2$ (w:v) with $10 \mathrm{mM}$ Tris/HCl buffer, $\mathrm{pH} 7.4$, containing deferoxamine mesylate (final concentration $2 \mathrm{mM}$ ). After $5 \mathrm{~min}$ incubation, samples were transferred to tubuline syringes and frozen in liquid nitrogen (Yegorov et al. 1993; Woodmansee and Imlay 2002). EPR measurements were carried out at $77 \mathrm{~K}$; microwave power, $10 \mathrm{~mW}$; time constant, $82 \mathrm{~ms}$; modulation amplitude, $5 \mathrm{G}$; centerfield 1,600 G; sweep width, $800 \mathrm{G}$ (Linares et al. 2003). A standard curve was generated using solutions of $\mathrm{Fe}_{2}\left(\mathrm{SO}_{4}\right)_{3} 7 \mathrm{H}_{2} \mathrm{O}$ in $200 \mu \mathrm{M} \mathrm{HCl}$ quantified spectrophotometrically $\left(\varepsilon_{420}=2.865 \mathrm{mM}^{-1} \mathrm{~cm}^{-1}\right.$ for the $\mathrm{Fe}^{3+}$ :desferal complex). All chemicals were prepared in iron free water, obtained from MilliQ water treated with chelex 100.

\section{Determination of the total iron content in tissues after}

Brumby and Massey (1967) and Lawrie et al. (1991)

Homogenates were heated at $50-60^{\circ} \mathrm{C}$ for at least $48 \mathrm{~h}$ until complete dryness. Afterwards samples were mineralised in $\mathrm{HNO}_{3}: \mathrm{HClO}_{4}(1: 1)$ and heated to dryness. The remaining inorganic residues were diluted in $4 \mathrm{ml} 5 \% \mathrm{HCl}$. After addition of $10 \%$ thioglycolic acid to convert Fe(III) to $\mathrm{Fe}(\mathrm{II})$, the concentration of $\mathrm{Fe}(\mathrm{II})$ was measured spectrophotometrically after reaction with $4 \mathrm{mM}$ bathophenanthroline at $535 \mathrm{~nm}$.

\section{Measurement of iron reduction according} to Vegh et al. (1988)

Samples were homogenised in $100 \mathrm{mM} \mathrm{KP} \mathrm{i}_{\mathrm{i}}$ buffer $\mathrm{pH} 7.4$ in $500 \mu \mathrm{l}$ final volume. To separate cell debris and lipids, homogenates were centrifuged for $8 \mathrm{~min}$ at $10,000 \mathrm{~g}$. The supernatant was mixed with $100 \mathrm{mM}$ Tris/ $\mathrm{HCl}$ buffer $\mathrm{pH}$ 7.4 and the iron reduction rate recorded spectrophotometrically at $520 \mathrm{~nm}, \varepsilon=13.6 \mathrm{mM}^{-1} \mathrm{~cm}^{-1}$, after adding $50 \mu \mathrm{M} \mathrm{Fe}$-EDTA, $11 \mathrm{mM} \alpha$ - $\alpha^{\prime}$-bipyridyl and $500 \mu \mathrm{M}$ $\mathrm{NADPH}$. Assays were carried out at room temperature.

Extraction of liver microsomes according to Klein et al. (1983)

A minimum of $0.6 \mathrm{~g}$ of liver tissue was needed for microsome extraction. Sample aliquots were pooled from 2 to 3 fish and homogenised in $9 \mathrm{ml}$ of $100 \mathrm{mM} \mathrm{KP}_{\mathrm{i}}$ buffer at $\mathrm{pH}$ 7.4. After centrifugation at $1,000 \mathrm{~g}$ for $10 \mathrm{~min}$ and $4^{\circ} \mathrm{C}$ to remove cell debris, the supernatant was again centrifuged for $1 \mathrm{~h}$ at $100,000 \mathrm{~g}$ and $4^{\circ} \mathrm{C}$ to precipitate the microsomal fraction. The resulting microsomal pellet was resuspended in $1.5 \mathrm{ml}$ of $125 \mathrm{mM} \mathrm{KCl}$, frozen in liquid nitrogen and stored at $-20^{\circ} \mathrm{C}$.

EPR-spin trapping of lipid radicals after Buettner (1987) in liver microsomes

Lipid radicals reflect the sensitivity of lipid membranes to ROS attack. Of each microsome solution $1 \mathrm{ml}$ was used. To initiate the lipid radical production the following reactants were added: $5.5 \mathrm{mM}$ ADP, $1 \mathrm{mM}$ NADPH, $0.1 \mathrm{mM}$ $\mathrm{Fe}\left(\mathrm{NH}_{4}\right)\left(\mathrm{SO}_{4}\right)_{2} \times 12 \mathrm{H}_{2} \mathrm{O}$ (in $\left.0.1 \mathrm{~N} \mathrm{HCl}\right)$. For later detection of the lipid radicals $100 \mathrm{mM}$ of the spin trap $\alpha$-(4-pyridyl 1oxide)- $N$-t-butyl nitrone (POBN) was added. After aggregation samples were frozen again in liquid nitrogen. Immediately before detection samples were thawed and lipid radical generation measured at room temperature using a Bruker spectrometer ECS 106, operating at $9.81 \mathrm{GHz}$ with $50 \mathrm{kHz}$ modulation frequency. After $30 \mathrm{~min}$ at room temperature lipid radical production of each sample was detected again to see the increase over time. EPR instrument settings were microwave power, $20 \mathrm{~mW}$; modulation amplitude, $1.194 \mathrm{G}$; time constant, $81.92 \mathrm{~ms}$; receiver gain, $2 \times 10^{4}$. Quantification was done using 4-OH TEMPO standard.

\section{Determination of enzymatic antioxidants}

Superoxide dismutase activity (SOD E.C: 1.15 .1 .1 ) was measured, since it is an important antioxidant enzyme, catalyzing the dismutation of superoxide to hydrogen peroxide. SOD activity was determined according to Livingstone et al. (1992), using a xanthine oxidase/cytochrome $c$ assay at $20^{\circ} \mathrm{C}$ and at the respective stress temperature of each experimental group. 1 Unit SOD was defined as the amount of protein that reduces the increase in extinction of superoxide-mediated reduction of oxidized cytochrome $c$ by $50 \%$ (measured at $550 \mathrm{~nm}$ ). 
Glutathione peroxidase activity $\left(\mathrm{GP}_{\mathrm{X}}\right)$ was also measured. $\mathrm{GP}_{\mathrm{X}}$ is a cytosolic hydrogen peroxide decomposing antioxidant enzyme. The activity was determined at $20^{\circ} \mathrm{C}$ in a coupled optical test according to Günzler and Flohe (1985). Oxidised glutathione GSSG is formed by the reaction of $\mathrm{GP}_{X}$ and continuously reduced by an excess of glutathione reductase (GR) activity, providing a constant level of GSH. The rate of NADPH oxidation by GR can be recorded spectrophotometrically at $340 \mathrm{~nm}$.

\section{Protein content after Bradford (1976)}

The protein content of the samples (except whole cell protein extracts for EMSA and Western blotting; see above) was determined by the Bradford method using bovine serum albumin as standard.

\section{Statistics}

All values are given as means \pm standard deviation. Differences between experimental groups were analysed by student's $t$-test using Statview 5.0. Significances were evaluated based on the $P$ level $<0.05$.

\section{Results}

Hypoxia inducible factor (HIF-1)

Western blots using an anti-HIF- $1 \alpha$ antibody, originally constructed against salmonid protein, identified constitutive amounts of HIF- $1 \alpha$ protein in both, summer and winter Z. viviparus liver samples (Fig. 1a). Despite high sequence homology between both zoarcid species (96\%; Heise, Lucassen, Abele unpublished results) the antibody did not detect the polar HIF- $1 \alpha$ protein. Although we did not detect significant differences between HIF- $1 \alpha$ protein levels in summer and winter $Z$. viviparus, electromobility shift assays demonstrated increased HIF-1 DNA binding in winter fish (Fig. 1a-c). Also, significantly higher HIF-1 DNA binding was observed in warm acclimated $\left(5^{\circ} \mathrm{C}\right)$ specimens of the polar eelpout, when compared to control fish at $0^{\circ} \mathrm{C}$. In several (three out of five) Z. viviparus summer individuals, and in four out of five $P$. brachycephalum maintained at $0^{\circ}$ control temperature, the EMSA signal was below detection limit and only marginal signals were detected in the other control fish. Bars in Fig. 1b represent means of all assays.

The interspecies comparison at the respective low water temperature yielded significantly higher HIF-binding to the EPO enhancer in North Sea winter fish than in polar eelpout at $0^{\circ} \mathrm{C}$.

\section{Oxidative stress parameters}

Table 1 summarises different oxidative stress and antioxidant parameters in the liver of both fish species under different seasonal (Z. viviparus) and experimental acclimation ( $P$. brachycephalum) conditions. Comparing North Sea winter fish to Antarctic control fish, we found less indication for lipid peroxidation (TBARS, $P<0.01$ ) and chemiluminescence $(P=0.04)$ in the polar eelpout, whereas protein carbonyl content was the same in both species $(P=0.59)$. SOD activities per $\mathrm{g}$ fresh weight were also lower in $P$. brachycephalum at standard assay temperature $\left(20^{\circ} \mathrm{C}, P=0.02\right)$, but similar $(P=0.59)$ when assayed at the respective low water temperatures for each species $\left(6^{\circ} \mathrm{C}\right.$ for $Z$. viviparus and $0^{\circ} \mathrm{C}$ for $P$. brachycephalum). Also glutathione peroxidase activities (measured at $\left.20^{\circ} \mathrm{C}\right)$ did not differ between both species $(P=0.89)$.

However, polar fish maintained higher levels of low molecular weight antioxidants, $\alpha$-tocopherol (Table 1; $n=2$ for the North Sea species; no statistical evaluation) and glutathione $(P<0.01$, Table 2$)$. The total glutathione content was threefold higher in the polar compared to the temperate species. Further, glutathione was much more oxidised (by $50 \%$ or more) in the liver of some polar specimens ( 8 out of 11) than in temperate fish liver. The oxidized glutathione redox ratio in some of the polar eelpout did, however, not lead to statistical significance between group means $(P=0.13)$.

Summer Z. viviparus had reduced TBARS $(P=0.03)$ and carbonyl contents $(P=0.04)$ and also mildly reduced tBOOH-induced chemiluminescence rates $(P=0.42)$ compared to winter fish. In line with these results, we measured higher activity of glutathione peroxidase (GPx; $P=0.05)$ in summer fish. Although SOD activity measured at standard assay temperature $\left(20^{\circ} \mathrm{C}\right)$ was lower in summer than in winter animals $(P<0.01)$, enzyme activities were the same in both seasons $(P=0.34)$ when assayed at the in situ temperature $\left(6^{\circ} \mathrm{C}\right.$ for winter and $12^{\circ} \mathrm{C}$ for summer $Z$. viviparus). Likewise, the total glutathione content, as given in Table 2, decreased in summer animals $(P<0.01)$ due to a decrease in the GSSG content $(P<0.01)$, while the GSH content remained unchanged between both seasonal groups $(P=0.69)$. This resulted in a significantly lower glutathione redox ratio $(P<0.01)$ and a significantly more reduced redox potential $(\Delta E ; P=0.02)$ in summer compared to winter $Z$. viviparus.

Warm acclimation to $5^{\circ} \mathrm{C}$ increased some but not all oxidative stress parameters in the polar species $P$. brachycephalum (Table 1). TBARS content was increased in warm acclimated $\left(5^{\circ} \mathrm{C}\right)$ versus control $\left(0^{\circ} \mathrm{C}\right)$ fish $(P=0.03)$, but protein carbonyl content $(P=0.22)$ and chemiluminescence rates $(P=0.34)$ were not affected by warming. Also $\alpha$-tocopherol content $(P=0.08)$ and SOD 

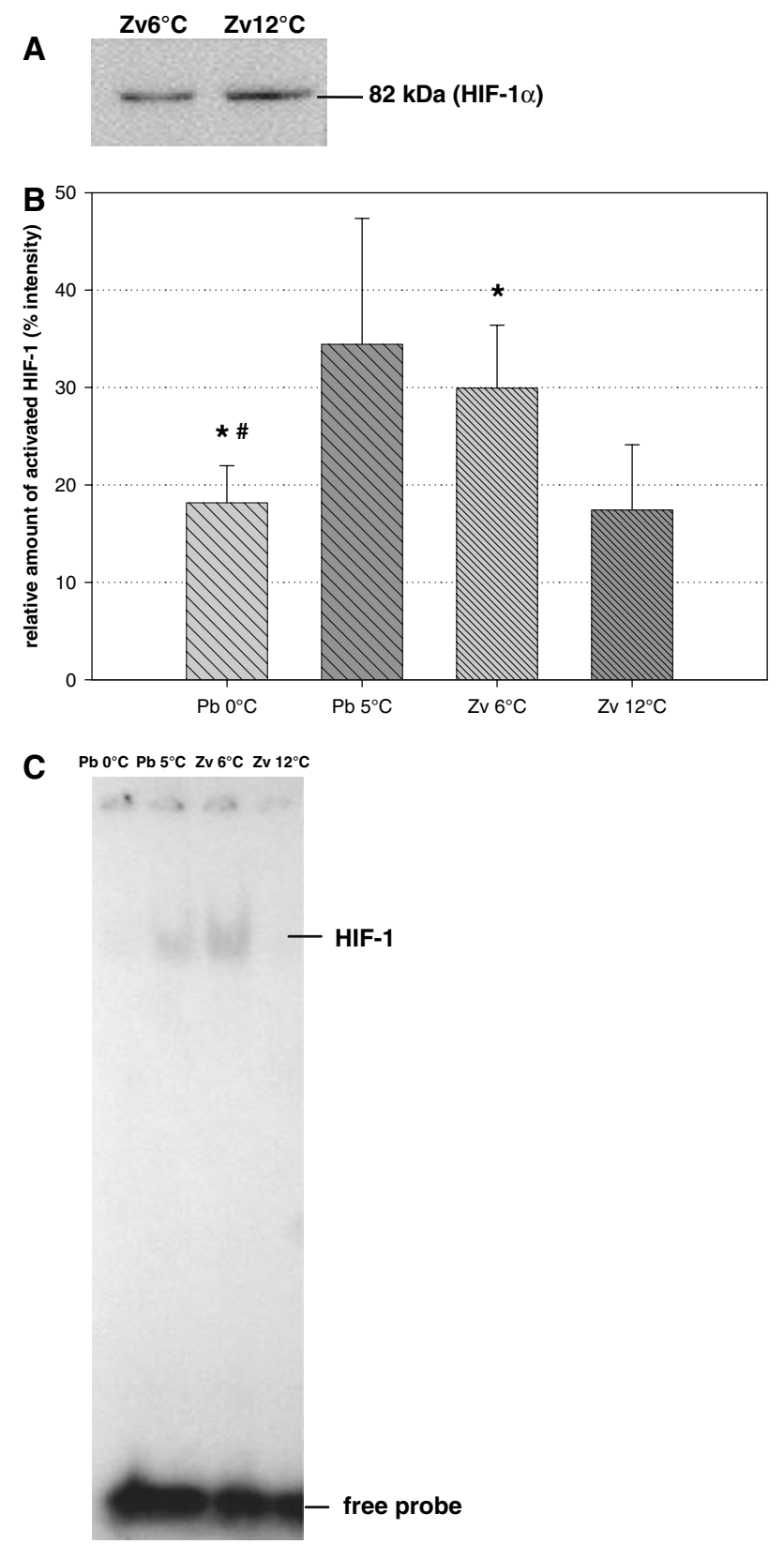

Fig. 1 HIF-1: a Western blotting analysis of HIF- $1 \alpha$ in liver whole cell extracts from the temperate eelpout Zoarces viviparus $(\mathrm{Zv})$ acclimatised to 6 and $12^{\circ} \mathrm{C}$. b HIF-1 DNA binding activity to the human EPO enhancer in electromobility shift assays with liver whole cell extracts from the polar eelpout Pachycara brachycephalum $(\mathrm{Pb})$ acclimated to 0 and $5^{\circ} \mathrm{C}$ as well as the temperate eelpout Zoarces viviparus $(\mathrm{Zv})$ acclimatised to 6 and $12^{\circ} \mathrm{C}$. Means \pm standard deviation, $n=5$. \% intensity was based on densitometry of gel images, with the sum of all four bands taken as $100 \%$ value. Interspecies comparison at the respective lower water temperature: \# significantly different from the North Sea species Z. viviparus, intraspecies comparison: $*$ significantly different from the values at the higher water temperature, $P<0.05$. c Example of EMSA

activity $\left(P=0.55\right.$ when measured at $20^{\circ} \mathrm{C} ; P=0.75$ at in situ temperature) were the same in both groups. Although GPx activity increased on warm acclimation
$(P=0.03$, Table 1$)$, all glutathione-related parameters remained unchanged (Table 2) in the high temperature group.

Lipid radical generation of isolated liver "microsomes"

As lipid radical EPR signals in liver homogenates were abolished by high cytosolic antioxidant potential, only the microsomal fraction was used in the assay. As individual liver samples did not yield sufficient sample volume, material had to be pooled from two or three liver samples. Lipid radicals combined with the spin trap POBN (alpha(4-pyridyl 1-oxide)- $N$-tert butylnitrone) resulted in adducts that gave a characteristic EPR spectrum with hyperfine coupling constants of $\mathrm{a}^{\mathrm{N}}=15.8$ and $2.6 \mathrm{G}$ in agreement with computer spectral simulated signals obtained using the same parameters (Fig. 2d). Even though these constants could be assigned to lipid radicals, spin trapping studies cannot readily distinguish between peroxyl (ROO·), alkoxyl (RO·) and alkyl (R.) adducts, owing to the similarity of the corresponding coupling constants (Buettner 1987).

EPR signals of lipid radical formation were fourfold higher in the pooled microsomes of polar eelpout (Fig. 2b, c; statistical testing was precluded by the small number of samples; two animal samples of the polar eelpout and three animals of the temperate eelpout), although the content of the lipid soluble antioxidant $\alpha$-tocopherol was also twofold elevated over the temperate species.

\section{Iron parameters}

Table 3 depicts measurements of different tissue iron fractions in whole liver homogenates of temperate winter fish versus polar eelpout. Whereas the total iron content was significantly lower in the polar zoarcid $(P<0.01)$, there was no significant difference between the species $(P=0.08)$ with respect to the content of labile iron. Labile iron is not strongly bound to enzymes or iron storage proteins and represents the catalytically available iron fraction. Iron reduction rates, enzymatic and non-enzymatic conversion of $\mathrm{Fe}(\mathrm{III})$ to the more powerful oxidising agent $\mathrm{Fe}(\mathrm{II})$, was also similar in liver homogenates from both fishes $(P=0.75)$. A doubling of iron reduction rate (measured at $20^{\circ} \mathrm{C}$ ) occurred in summer eelpout from the North Sea, as compared to winter rates $(24 \pm 6$ in summer and $11 \pm 5 \mu \mathrm{mol} \mathrm{g}$ fresh weight ${ }^{-1} \mathrm{~min}^{-1}$ in winter; $P=0.04$ ). Contrary to $Z$. viviparus, acclimation of polar eelpout to higher temperatures had no inducing effect on iron reductase activity $\left(10 \pm 4\right.$ at $0^{\circ} \mathrm{C}$ and $12 \pm 1 \mu \mathrm{mol} \mathrm{g}$ fresh weight ${ }^{-1} \min ^{-1}$ for $P$. brachycephalum at $5^{\circ} \mathrm{C}$, $P=0.46)$. 
Table 1 Summarizes oxidative stress marker (thiobarbituric reactive substances (TBARS), chemiluminescence, carbonyl content) and antioxidant defence [superoxide dismutase (SOD), glutathione peroxidase, $\alpha$-tocopherol] in liver samples from the polar eelpout Pachycara brachycephalum $(\mathrm{Pb})$ acclimated to 0 and $5^{\circ} \mathrm{C}$ as well as the temperate eelpout Zoarces viviparus ( $\mathrm{Zv}$ ) acclimatised to 6 and $12^{\circ} \mathrm{C}$

\begin{tabular}{|c|c|c|c|c|}
\hline & $\begin{array}{l}\text { P. brachycephalum } \\
\left(0^{\circ} \mathrm{C}\right)\end{array}$ & $\begin{array}{l}\text { P. brachycephalum } \\
\left(5^{\circ} \mathrm{C}\right)\end{array}$ & $\begin{array}{l}\text { Z. viviparus } \\
\left(6^{\circ} \mathrm{C} \text {, winter }\right)\end{array}$ & $\begin{array}{l}\text { Z. viviparus } \\
\left(12^{\circ} \mathrm{C} \text {, summer }\right)\end{array}$ \\
\hline TBARS $\left(\mu \mathrm{mol} \mathrm{g} \mathrm{FW}^{-1}\right)$ & $0.17 \pm 0.05(* / \#)$ & $0.26 \pm 0.05$ & $0.6 \pm 0.1(*)$ & $0.4 \pm 0.1$ \\
\hline Chemiluminescence rate $\left(\mathrm{cpm}^{2} \mathrm{mg}\right.$ protein $\left.{ }^{-1}\right)$ & $0.3 \pm 0.1(\mathrm{NS} / \#)$ & $0.4 \pm 0.3$ & $1.1 \pm 0.8(\mathrm{NS})$ & $0.6 \pm 0.3$ \\
\hline Carbonyl content (nmol mg protein ${ }^{-1}$ ) & $4 \pm 2(\mathrm{NS} / \mathrm{NS})$ & $6 \pm 2$ & $3.2 \pm 0.4(*)$ & $2.2 \pm 0.7$ \\
\hline SOD activity $\left(20^{\circ} \mathrm{C}\right)\left(\mathrm{U} \mathrm{g} \mathrm{FW}^{-1}\right)$ & $2200 \pm 800(\mathrm{NS} / \#)$ & $2400 \pm 200$ & $3400 \pm 500(*)$ & $2000 \pm 700$ \\
\hline SOD activity (water temperature) $\left(\mathrm{U} \mathrm{g} \mathrm{FW}^{-1}\right)$ & $2000 \pm 400(\mathrm{NS} / \mathrm{NS})$ & $2100 \pm 400$ & $2000 \pm 1000(\mathrm{NS})$ & $1800 \pm 500$ \\
\hline Glutathione peroxidase $\left(20^{\circ} \mathrm{C}\right)\left(\mathrm{U} \mathrm{g} \mathrm{FW}^{-1}\right)$ & $1.6 \pm 0.5(* / \mathrm{NS})$ & $2.6 \pm 0.7$ & $1.6 \pm 0.6(*)$ & $4 \pm 2$ \\
\hline$\alpha$-tocopherol $\left(\mu \mathrm{mol} \mathrm{g} \mathrm{FW}{ }^{-1}\right)$ & $300 \pm 200(\mathrm{NS} /-)$ & $500 \pm 100$ & $93(-)$ & $240 \pm 80$ \\
\hline
\end{tabular}

Means \pm standard deviation, $n=4-7, n=2$ for $\alpha$-tocopherol of $\mathrm{Zv} 6^{\circ} \mathrm{C}$. Interspecies comparison at the respective lower water temperature: \# significantly different to the North Sea species Z. viviparus, intraspecies comparison: * significantly different to the values at the higher water temperature, NS not significant, - no statistical evaluation because $n=2, P<0.05$. $F W$ fresh weight

Table 2 Depicts glutathione redox parameters: the contents of reduced (GSH) and oxidised glutathione (GSSG), total glutathione content and the ratio of oxidised to reduced glutathione

\begin{tabular}{lcccc}
\hline & $\begin{array}{l}P . \text { brachycephalum } \\
\left(0^{\circ} \mathrm{C}\right)\end{array}$ & $\begin{array}{l}\text { P. brachycephalum } \\
\left(5^{\circ} \mathrm{C}\right)\end{array}$ & $\begin{array}{l}\text { Z. viviparus } \\
\left(6^{\circ} \mathrm{C} \text {, winter }\right)\end{array}$ & $\begin{array}{l}\text { Z. viviparus } \\
\left(12^{\circ} \mathrm{C}, \text { summer }\right)\end{array}$ \\
\hline $\left.\mathrm{GSH}(\mu \mathrm{mol} \mathrm{g} \mathrm{FW})^{-1}\right)$ & $2.1 \pm 0.5(\mathrm{NS} / \#)$ & $2.4 \pm 0.3$ & $1.0 \pm 0.4(\mathrm{NS})$ & $0.9 \pm 0.3$ \\
$\left.\mathrm{GSSG}(\mu \mathrm{mol} \mathrm{g} \mathrm{FW})^{-1}\right)$ & $3.1 \pm 1.5(\mathrm{NS} / \#)$ & $2.9 \pm 0.8$ & $0.8 \pm 0.2(*)$ & $0.16 \pm 0.05$ \\
Total glutathione $\left.(\mathrm{GSH}+2 \mathrm{GSSG})(\mu \mathrm{mol} \mathrm{g} \mathrm{FW})^{-1}\right)$ & $8 \pm 2(\mathrm{NS} / \#)$ & $9 \pm 3$ & $2.5 \pm 0.5(*)$ & $1.2 \pm 0.3$ \\
$(2 \mathrm{GSSG}) / \mathrm{GSH}$ & $2.7 \pm 0.9(\mathrm{NS} / \#)$ & $3 \pm 1$ & $1.8 \pm 0.9(*)$ & $0.36 \pm 0.041$ \\
Redox potential $\Delta E(\mathrm{mV})$ & $-253 \pm 5(\mathrm{NS} / \#)$ & $-252 \pm 8$ & $-246 \pm 11(*)$ & $-258 \pm 4$ \\
\hline
\end{tabular}

The redox potential $(\Delta E)$ was calculated at respective water temperature and in situ intracellular $\mathrm{pH}\left(\mathrm{pH}_{\mathrm{i}}\right)$ calculated by the Nernst equation as described in Schafer and Buettner (2001). Changes of $\mathrm{pH}_{\mathrm{i}}$ with temperature were elaborated for muscle tissue by Sartoris et al. (2003) and corrected for lower liver $\mathrm{pH}_{\mathrm{i}}$ values by $0.28 \mathrm{pH}$ units (Larsen et al. 1997). Values are given for liver tissue of the polar eelpout Pachycara brachycephalum $(\mathrm{Pb})$ acclimated to 0 and $5^{\circ} \mathrm{C}$ as well as the temperate eelpout Zoarces viviparus $\left(\mathrm{Zv}\right.$ ) acclimatised to 6 and $12^{\circ} \mathrm{C}$. Means \pm standard deviation, $n=4-7$. Interspecies comparison at the respective lower water temperature: \# significantly different to the North Sea species $Z$. viviparus, intraspecies comparison: * significantly different to the values at the higher water temperature, $N S$ not significant, - no statistical evaluation, $P<0.05$. $F W$ fresh weight

\section{Discussion}

HIF signalling: increased in polar fish and in temperate fish in winter

HIF-1 binding to the human EPO-enhancer fragment was significantly higher at low temperature both in the interspecies comparison, polar versus temperate eelpout, as well as when comparing summer and winter acclimated temperate fish (Z. viviparus). This agrees with previous findings from cold shock experiments with $Z$. viviparus, which also resulted in increased HIF-1 DNA-binding (Heise et al. 2006a) already after $2 \mathrm{~h}$. HIF-dependent signalling seems to be instrumental in the physiological response to low temperature in North Sea eelpout. Provided HIF-1 acts on the same target genes as in mammalian tissues (erythropoiesis, angiogenesis and anaerobic glycolysis) this would improve oxygen transport and anaerobic energy production within central tissues, like the liver at low temperatures. However, HIF target genes remain to be specified in fish, and even the genes generally activated during seasonal cold adaptation or cold acclimation are still under investigation (Gracey et al. 2004).

In Antarctic stenothermal eelpout, increased HIF-1DNA binding to the EPO-enhancer over the $0^{\circ} \mathrm{C}$ control levels occurred upon warming to $5^{\circ} \mathrm{C}$, a temperature close to the upper tolerance limit but well tolerated by this species (Mark et al. 2002a; Lannig et al. 2005). Similarly, warming from 12 to $18^{\circ} \mathrm{C}$ (but not to above $20^{\circ} \mathrm{C}$ ) stimulated enhanced HIF-1-DNA binding in the temperate eelpout (Heise et al. 2006b). It therefore appears that HIF-1 could be a common regulator for the adjustment of tissue oxygenation towards the border of the thermal range of a fish but no longer at extreme temperatures. 


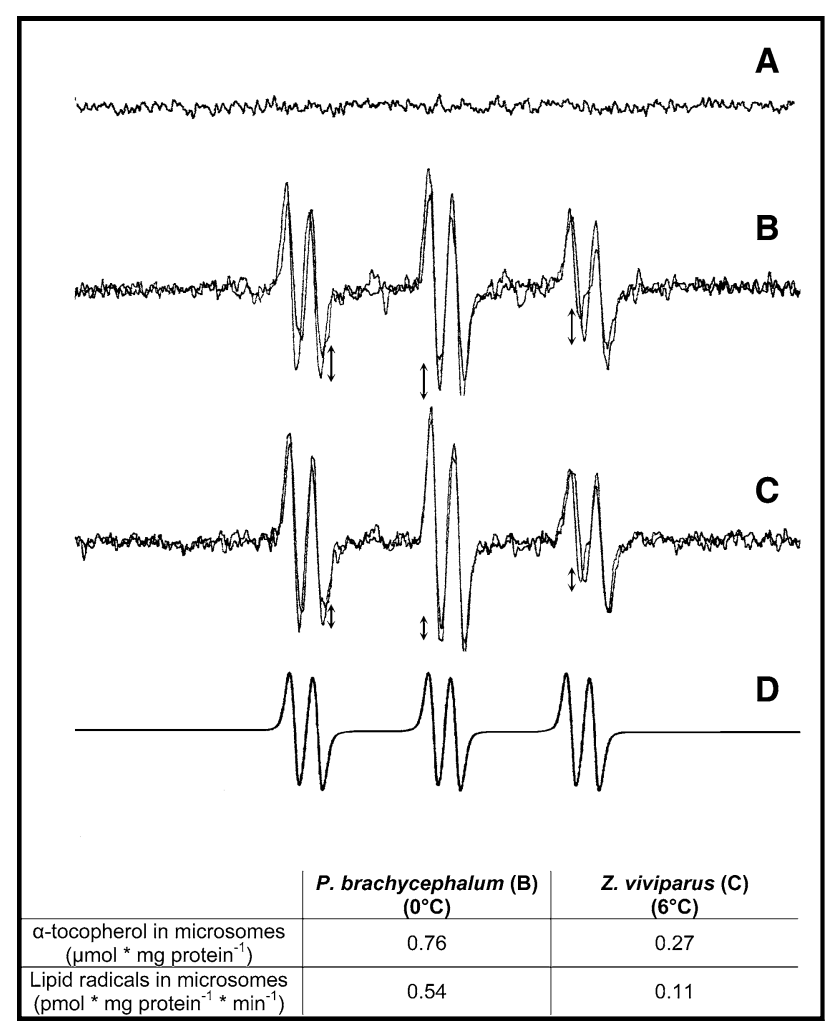

Fig. 2 EPR detection of lipid radical formation by liver microsomal extracts. a shows POBN spectra. b Overlay of lipid radical generation at $t=0$ and $30 \mathrm{~min}$ in the polar eelpout Pachycara brachycephalum. c Overlay of lipid radical generation at $t=0$ and $30 \mathrm{~min}$ in the temperate eelpout Zoarces viviparus. d Depicts computer simulated spectra of lipid radicals. Arrows indicate the higher lipid radical generation in the polar eelpout upon 30 min incubation compared to the temperate eelpout. The inserted table gives the values of $\alpha$ tocopherol content and lipid radical formation rates in liver microsomes from both species

Table 3 Depicts measurements of different iron parameters (total iron content, total intracellular labile iron detected by EPR, iron reduction rate $\mathrm{Fe}(\mathrm{III})$ to $\mathrm{Fe}(\mathrm{II})$ ) in liver homogenates of the polar eelpout Pachycara brachycephalum $(\mathrm{Pb})$ and the temperate eelpout Zoarces viviparus $(\mathrm{Zv})$

\begin{tabular}{llll}
\hline & $\begin{array}{l}\text { P. brachycephalum } \\
\left(0^{\circ} \mathrm{C}\right)\end{array}$ & $\begin{array}{l}\text { Z. viviparus } \\
\left(6^{\circ} \mathrm{C}\right)\end{array}$ & \\
\hline $\begin{array}{c}\text { Total iron content } \\
(\mathrm{nmol} \mathrm{g} \mathrm{FW})\end{array}$ & $37 \pm 10$ & $150 \pm 20$ & (\#) \\
$\begin{array}{c}\text { Total intracellular labile } \\
\left.\text { iron (nmol g FW }{ }^{-1}\right)\end{array}$ & $22 \pm 4$ & $34 \pm 7$ & (NS) \\
$\begin{array}{l}\text { Ratio of labile iron/ } \\
\text { total iron }\end{array}$ & 0.59 & 0.22 & $(-)$ \\
$\begin{array}{c}\text { Iron reduction rate } \\
\left(\mu \mathrm{mol} \mathrm{g} \mathrm{FW}^{-1} \mathrm{~min}^{-1}\right)\end{array}$ & $10 \pm 4$ & $11 \pm 5$ & (NS) \\
\hline
\end{tabular}

\# significant difference of the two species compared at the low water temperature, NS not significant, - no statistical evaluation, as values were obtained from pooled samples in microsomal isolates or calculated from mean values (ratio "free"/total iron), $P<0.05, n=3-5$, $n=2$ for "free" iron of $\mathrm{Zv} 6^{\circ} \mathrm{C}$. $F W$ fresh weight
HIF stabilisation in fish: short term changes versus long term adjustments

In this study as well as in earlier investigations of HIF response to hypoxia and temperature change in fish, HIF$1 \alpha$ protein levels and HIF- 1 DNA binding activity were detected also under normoxic, unstressed conditions in vivo (Stroka et al. 2001; Rissanen et al. 2006; Heise et al. 2006a, b). This contrasts findings in mammalian cellular systems (e.g. human hepatoma cell lines) where the HIF- $1 \alpha$ protein is detectable only under severe oxygen deprivation (1-0.1\% oxygen) because PHD activity is compromised due to the lack of oxygen (Huang et al. 1996; Doege et al. 2005). Actually, the half-life of HIF- $1 \alpha$ at atmospheric $\mathrm{pO}_{2}$ in these cellular systems has been estimated to $<5$ min whereas its hypoxic stabilization happens instantaneously (Huang and Bunn 2003). Indeed, fish HIF$1 \alpha$ protein is detectable in rainbow trout hepatocytes at $21 \%$ oxygen and is further induced upon lowering the oxygen concentration to 5\% oxygen (38 torr) (Soitamo et al. 2001) which is well within the physiological oxygenation range of these cells.

What mechanism could be involved in stabilizing HIF in normoxic fish and at physiological intracellular oxygen concentration in vivo? Nikinmaa et al. (2004) found that more reduced cellular redox conditions had a stabilising effect on the HIF- $1 \alpha$ protein in salmonid cells. Like Huang et al. (1996) in their study of human hepatoma cell lines, Nikinmaa's group suggested that the reduction state of several functionally important cysteine residues could play an important role in the regulation of HIF- $1 \alpha$ protein subunit stability. In in vivo heat and cold exposure experiments with eelpout, we found clear evidence of a more reduced glutathione redox ratio correlating with higher HIF-1 DNA-binding activity in eelpout liver tissue (Heise et al. 2006a, b). Thus, redox potential may modify HIF functioning generally in fish within the short term response to changing environmental conditions, and oxygen radicals formed in response to acute warming may well be involved in reducing or abrogating the HIF signal through generation of a more oxidized tissue redox state. The doubling of the iron reduction rate in summer fish liver may further support down regulation of HIF- $1 \alpha$, because $\mathrm{Fe}(\mathrm{II})$ enhances PHD activity.

In the present study of seasonal acclimatisation to winter cold, the North Sea eelpout still showed higher HIF-1 binding in the liver at low temperature, but at a significantly more oxidised tissue redox state than in summer specimens. Several oxidative stress markers were simultaneously increased in winter $Z$. viviparus compared to the summer fish. Similarly, in the Antarctic P. brachycephalum increased HIF-1 DNA binding occurred despite higher lipid peroxidation levels (TBARS) and undiminished oxidation 
of the glutathione redox ratio in liver of fishes warmed over 11 weeks. Therefore, either other signalling mechanisms than the cellular redox potential may have been effecting elevated HIF-1 binding during winter cold (Z.viviparus) and prolonged warming ( $P$. brachycephalum), or the transcription factor response to the cellular redox signal is changed during seasonal cold acclimatization. The interaction of heat shock protein (HSP) with the HIF- $1 \alpha$ subunit has been suggested as a putative mechanism stabilizing HIF (Minet et al. 1999; Katschinski et al. 2002; Rissanen et al. 2006). Further investigations are needed here to confirm whether or not HIF stabilization is supported by HSP interaction upon warming (and perhaps cooling) in marine ectotherms, an alternative mechanism that would be completely independent of tissue redox state.

Is oxidative stress higher in polar than temperate eelpout?

Higher levels of lipid unsaturation in combination with the enhanced aqueous oxygen solubility at low temperatures are two possible causes for higher sensitivity of polar ectotherms to oxidative stress (for review see Abele and Puntarulo 2004). Elevated sensitivity of polar fish membranes to ROS attack has been documented in several papers (Gieseg et al. 2000; Dunlap et al. 2002). Indeed, Antarctic eelpout contain higher concentrations of unsaturated membrane fatty acids than North Sea eelpout, although these are primarily monounsaturated compounds (Brodte et al. 2006a) which, in contrast to polyunsaturated fatty acids, do not give rise to enhanced ROS formation (Hulbert 2006). However, the higher susceptibility to oxidative stress in liver of polar eelpout became evident when comparing both species at the respective low habitat temperature $\left(P\right.$. brachycephalum $0^{\circ} \mathrm{C} ; Z$. viviparus $\left.6^{\circ} \mathrm{C}\right)$. Whereas rates of lipid radical generation (Fig. 2b, c) were indeed higher in isolated liver microsomes of $P$. brachycephalum, the concentration of the lipid peroxidation indicator (TBARS) amounted only to one half of that found in $Z$. viviparus. Lipid radical formation was detectable only in liver microsomes void of antioxidants, but not in liver tissue homogenates containing the antioxidants. Also, the lower rates of $\mathrm{tBOOH}$-induced chemiluminescence in $P$. brachycephalum compared to $Z$. viviparus tissue homogenate speak for a higher antioxidant capacity in the Antarctic eelpout (Gonzalez Flecha et al. 1991). Indeed, the radical electron scavenger glutathione was two to three times more concentrated in polar compared to temperate eelpout liver, and superoxide dismutase activity was fully compensated for at the Antarctic water temperature. The difference in glutathione redox ratio (GSSG:GSH) between both eelpout species, albeit not statistically significant $(P=0.13)$, indicates that the liver redox potential of the polar eelpout was more oxidised than that of the temperate eelpout. We are not aware of any literature data reporting a higher GSSG/GSH ratio higher than that in the polar eelpout in the present study. Thus, polar eelpout are more susceptible but at the same time better protected from oxidative damage than their North Sea confamilials, and only the highly oxidized glutathione redox ratio suggests that they have to deal with increased oxidative stress levels.

High and highly oxidized glutathione concentrations in polar fish

The high degree of glutathione oxidation is quite surprising, as GSSG rarely exceeds $10 \%$ of total glutathione levels in healthy cells (Kidd 1997). Generally, over-produced GSSG molecules are rapidly exported from hepatocytes because they can have deleterious effects on cell integrity and physiological processes (Reed 1990). Through proteinS-thiolation, GSSG can modify the activity of important metabolic enzymes (Han et al. 2006). However, the highly oxidised glutathione redox state is obviously well tolerated in $P$. brachycephalum and it may well be a characteristic trait of some polar fish that metabolic processes, adapted to function at low temperatures, are also apt to operate in a more oxidised redox environment.

Glutathione data from other Antarctic fish are still missing, but comparing polar and temperate mud clams (Philipp et al. 2005) and scallops (Philipp et al. 2006) we found twice as high glutathione concentrations in mantle tissue of the polar animals, and also two-times more oxidised glutathione redox ratios in the polar than the temperate bivalves. We take this as a hint that especially in epibenthic polar ectotherms the tissue redox state may be more oxidised than in comparable temperate animals (for review see Abele et al. 2007).

\section{Differences in iron metabolism between polar} and temperate eelpout

Different iron parameters were determined, as reduced ferrous iron, $\mathrm{Fe}(\mathrm{II})$, is a possible catalyst of Fenton reactions in which highly reactive hydroxyl radicals $(\cdot-\mathrm{OH})$ are generated (Halliwell and Gutteridge 1985) and are an immediate cause of oxidative stress. Binding of iron to ferritin is one of the most powerful antioxidant mechanisms in living tissues, as it prevents the iron from acting as Fenton catalyst. Also, Fe(II) is a PHD cofactor and supports HIF- $1 \alpha$ degradation. Despite lower overall iron concentrations in polar than in temperate eelpout liver, differences of labile iron between both fishes were not statistically significant, indicating the same potential to promote Fenton reactions. This is further supported by similar rates of iron reduction, converting $\mathrm{Fe}$ (III) to the 
more powerful oxidising agent $\mathrm{Fe}(\mathrm{II})$, in liver homogenates of both fishes. A doubling of the iron reduction rate (measured at $20^{\circ} \mathrm{C}$ ) in North Sea summer fish as compared to winter activities reflects intensified iron metabolism in $Z$. viviparus, to maintain higher turnover of heme proteins in the more active summer fish. In contrast to Z. viviparus, acclimation of polar eelpout to higher temperatures had no inducing effect on iron reductase activity, which, e.g., indicates that $\mathrm{Fe}$ (II) availability was not limiting PHD activity in the polar fish.

Molecular adjustments during long-term and seasonal thermal adaptation in fish

Taken together, the data obtained for eelpout in this and parallel studies can be merged into a concept, describing the involvement of HIF within the other molecular adjustments during adaptation of the fish to long-term (stenothermal polar eelpout) and seasonal (eurythermal North Sea eelpout) temperature change. In this context it seems important to emphasise that rapid regional climate change, currently observed in the Western Antarctic, is already leading to anomalous warming of deep water in coastal and shelf areas of the Peninsula, the habitat of Pachycara brachycephalum, so that this polar species already faces episodic and possibly progressive environmental warming which exploits its present capacity of acclimation (Brodte et al. 2006c).

We have shown that seasonal cold in North Sea fish and experimental warming in polar eelpout both cause higher HIF activity in the liver. Both thermal challenges were subcritical for the fish, which means that the HIF activation is part of molecular regulation and not a stress response in this case. It presumably facilitates oxygen transport within the liver at both ends of the species specific thermal tolerance range, possibly by inducing erythropoietin and angiogenic factors like the vascular endothelial growth factor (VEGF). Nitric oxide synthase (NOS) is another important HIF target gene. Its catalytic product nitric oxide (NO) is an inhibitor of the mitochondrial end oxidase (cytochrome- $c$ oxidase) which reduces mitochondrial oxygen consumption (Cleeter et al. 1994; Atunes et al. 2004). A HIF/NO induced down regulation of mitochondrial oxygen consumption upon cold exposure of North Sea fish might enable a more homogeneous distribution of oxygen also within the central regions of the organ under conditions of thermally reduced oxygen diffusion.

Interestingly, Mark et al. (2006b) found the mitochondrial uncoupling protein UCP2 over expressed following 2 months of cold acclimation at $2^{\circ} \mathrm{C}$ in the North Sea eelpout, as well as following prolonged warm acclimation to $5^{\circ} \mathrm{C}$ in the polar eelpout. Thus, UCP expression parallels the increased HIF activity found in the present study. The authors discussed the possible involvement of UCP-catalyzed mitochondrial uncoupling in the context of mitigation of mitochondrial ROS formation at both thermal extremes. Indeed, mild uncoupling in the cold could control cellular oxygen concentration from becoming too high and inducing excess ROS formation. Already under the present conditions, liver glutathione was significantly more oxidized in winter $Z$. viviparus, indicating a higher ROS output in cold adapted winter animals. It seems possible that, especially during cold adaptation, HIF and UCPs contribute to the concerted stabilization of tissue oxygen in the liver, not too low to render cells hypoxic and not too high to cause oxidative damage.

Acknowledgments The authors would like to thank Maike Schmidt for her help in preparing the fish samples, as well as Tamara Zaobornyj and Laura Valdez for adjusting the chemiluminescence assay protocol to fish liver tissue. We further thank Hanna Tranberg, Eeva Rissanen and Kristiina Vuori for their contribution to adjust EMSA and Western blot methodology to eelpout samples. This study was supported by grants from Deutscher Akademischer Austauschdienst (DAAD) to $\mathrm{KH}$.

\section{Reference}

Abele D, Puntarulo S (2004) Formation of reactive species and induction of antioxidant defence systems in polar and temperate marine invertebrates and fish. Comp Biochem Physiol 138A:405-415

Abele D, Philipp E, Gonzalez P, Puntarulo S (2007) Marine invertebrate mitochondria and oxidative stress. Front Biosci 12:933-946

Acker T, Acker H (2004) Cellular oxygen sensing need in CNS function: physiological and pathological implications. J Exp Biol 207:3171-3188

Acker T, Fandrey J, Acker H (2006) The good, the bad and the ugly in oxygen sensing: ROS, cytochromes and prolyl-hydroxylases. Cardiovasc Res 71:195-207

Atunes F, Boveris A, Cadenas E (2004) On the mechanism and biology of cytochrome oxidase inhibition by nitric oxide. PNAS 101:16774-16779

Buettner GR (1987) Spin trapping: ESP parameters of spin adducts. Free Rad Biol Med 3:259-303

Bradford MM (1976) A rapid and sensitive method for the quantification of microgram quantities of protein utilizing the principle of protein-dye binding. Anal Biochem 71:248-254

Brodte E, Graeve M, Jacob U, Knust R, Pörtner H-O (2006a) Temperature dependent lipid levels and components in polar and temperate eelpout (Zoarcidae). Fish Physiol Biochem (in press)

Brodte E, Knust R, Pörtner H-O, Arntz WE (2006b) Biology of the Antarctic eelpout Pachycara brachycephalum. Deep-Sea Res 53:1131-1140

Brodte E, Knust R, Pörtner HO (2006c) Temperature dependent energy allocation to growth in Antarctic and boreal eelpout (Zoarcidae). Polar Biol doi:10.1007/s00300-006-0165-y

Brumby PE, Massey V (1967) Determination of non-heme iron, total iron and copper. Methods Enzymol 10:464-472

Cleeter MWJ, Cooper JM, Darley-Usmar VM, Moncada S, Schapira AHV (1994) Reversible inhibition of cytochrome $c$ oxidase, the terminal enzyme of the mitochondrial respiratory chain, by nitric oxide. Implications for neurodegenerative diseases. FEBS Lett 345:50-54 
Czubryt MP, Panagia V, Pierce GN (1996) The roles of free radicals, peroxides and oxidized lipoproteins in second messenger system dysfunction. EXS 76:57-69

Desai I (1984) Vitamin E analysis methods for animal tissues. Methods Enzymol 105:138-146

Doege K, Heine S, Jensen I, Jelkmann W, Metzen E (2005) Inhibition of mitochondrial respiration elevates oxygen concentration but leaves regulation of hypoxia-inducible factor (HIF) intact. Blood 106:2311-2317

Dunlap WC, FujisawaA, Yamamoto Y, Moylan TJ, Sidell BD (2002) Notothenoid fish, krill and phytoplankton from Antarctica contain a vitamin $\mathrm{E}$ constituent ( $\alpha$-tocopherol) functionally associated with cold-water adaptation. Comp Biochem Physiol 133B:299-305

Egginton S, Sidell BD (1989) Thermal acclimation induces adaptive changes in subcellular structure of fish skeletal muscle. Am J Physiol 256:R1-R9

Fandrey J, Gorr TA, Gassmann M (2006) Regulating cellular oxygen sensing by hydroxylation. Cardiovasc Res 71:642-651

Fariss MW, Reed DJ (1987) High-performance liquid chromatography of thiols and disufides: diphenol derivatives. Methods Enzymol 143:101-109

Gieseg SP, Cuddihy S, Hill JV, Davison W (2000) A comparison of plasma vitamin $\mathrm{C}$ and $\mathrm{E}$ levels in two Antarctic and two temperate water fish species. Comp Biochem Physiol 125B:371378

Gonzalez Flecha B, Llesuy S, Boveris A (1991) Hydroperoxideinitiated chemiluminescence: an assay for oxidative stress in biopsies of heart, liver, and muscle. Free Rad Biol Med 10:93100

Gorr TA, Gassmann M, Wappner P (2006) Sensing and responding to hypoxia via HIF in model invertebrates. J Insect Physiol 52:349364

Gracey AY, Fraser FJ, Li W, Fang Y (2004) Coping with cold: an integrative analysis of the transcriptome of a poikilothermic vertebrate. Proc Natl Acad Sci USA 101(48):16970-16975

Günzler WA, Flohe L (1985) Glutathione peroxidase. In: Greenwald RA (ed) CRC handbooks of methods for oxygen radical research. CRC, Boca Raton, pp 285-289

Haddad JJE, Olvers RE, Land SC (2000) Antioxidant/pro-oxidant equilibrium regulates HIF- $1 \alpha$ and NF- $\kappa \mathrm{B}$ redox sensitivity. J Biol Chem 275:21130-21139

Halliwell B, Gutteridge JMC (1985) Free radicals in biology and medicine, 2nd edn. Clarendon, Oxford, pp 1-543

Han D, Hanawa N, Saberi B, Kaplowitz N (2006) Mechanisms of liver injury: role of glutathione redox status in liver injury. Am $\mathrm{J}$ Physiol Gastrointest Liver Physiol 291:G1-G7

Heise K, Puntarulo S, Nikinmaa M, Lucassen M, Pörtner HO, Abele D (2006a) Oxidative stress and HIF-1 DNA binding during stressful cold exposure and recovery in the North Sea eelpout (Zoarces viviparus). Comp Biochem Physiol 143A:494-503

Heise K, Puntarulo S, Nikinmaa M, Abele D, Pörtner HO (2006b) Oxidative stress during stressful heat exposure and recovery in the North Sea eelpout (Zoarces viviparus). J Exp Biol 209:353363

Huang LE, Arany Z, Livingston DM, Bunn FH (1996) Activation of hypoxia-inducible transcription factor depends primarily upon redox-sensitive stabilization of its $\alpha$-subunit. J Biol Chem 271(50):32253-32259

Huang LE, Bunn FH (2003) Hypoxia-inducible factor and its biomedical relevance. J Biol Chem 278(22):19575-19578

Hulbert AJ (2006) The link between membrane composition, metabolic rate and lifespan. Comp Biochem Physiol A (in press)

Ivan M, Kondo K, Yang H, Kim W, Valiando J, Ohh M, Salic A, Asara JM, Lane WS, Kaelin WG Jr (2001) HIF $\alpha$ targeted for
VHL-mediated destruction by proline hydroxylation: implications for $\mathrm{O}_{2}$ sensing. Sci 292:464-468

Johnston IA (1982) Capillarisation, oxygen diffusion distances and mitochondrial content of carp muscles following acclimation to summer and winter temperatures. Cell Tissue Res 222:325-337

Katschinski DM, Le L, Heinrich D, Wagner KF, Hofer T, Schindler SG, Wenger RH (2002) Heat induction of the unphosphorylated form of hypoxia-inducible factor- $1 \alpha$ is dependent on heat shock protein-90 activity. J Biol Chem 277:9262-9267

Kidd PM (1997) Glutathione: systemic protectant against oxidative and free radical damage. Alt Med Rev 1:155-176

Klein SM, Cohen G, Lieber CS, Cederbaum AI (1983) Increased microsomal oxidation of hydroxy radical scavengers and ethanol after chronic consumption of ethanol. Arch Biochem Biophys 223:425-433

Kvietikova I, Wenger RH, Marti HH, Gassmann M (1995) The transcription factors ATF-1 and CREB-1 bind constitutively to the hypoxia-inducible factor-1 (HIF-1) DNA recognition site. Nucl Acids Res 23:4542-4550

Lannig G, Storch D, Pörtner H-O (2005) Aerobic mitochondrial capacities in Antarctic and temperate eelpout (Zoarcidae) subjected to warm versus cold acclimation. Polar Biol 28:575584

Larsen B., Pörtner HO, Jensen FB (1997) Extra- and intracellular acid-base balance and ionic regulation in cod (Gadus morhua) during combined and isolated exposures to hypercapnia and copper. Marine Biol 128:337-346

Law S, Wu R, Ng P, Yu R, Kong R (2006) Cloning and expression analysis of two distinct HIF-alpha isoforms-gcHIF-1alpha and gcHIF-4alpha-from the hypoxia-tolerant grass carp, Ctenopharyngodon idellus. BMC Mol Biol 7:15 doi:10.1186/14712199-7-15

Lawrie S, Tancock N, McGrowth N, Roger J (1991) Influence of complexation of the uptake by plants of iron, manganese, copper and zinc. I Effect of EDTA in a multimetal and computer simulation study. J Exp Biol 42:509-515

Levine RL, Garland D, Oliver CN, Amici A, Climent I, Lenz A-G, Ahn B-W, Shaltiel S, Stadtman ER (1990) Determination of carbonal content in oxidatively modified proteins. Methods Enzymol 186:464-485

Linares E, Nakao LS, Augusto O, Kadiiska MB (2003) EPR studies of in vivo radical production by lipopolysaccharide: potential role of iron mobilized from iron-nitrosyl complexes. Free Rad Biol Med 34:766-773

Livingstone DR, Lips F, Martinez PG, Pipe RK (1992) Antioxidant enzymes in the digestive gland of the common mussel Mytilus edulis. Marine Biol 112:265-276

Mark FC, Bock C, Pörtner HO (2002a) Oxygen-limited thermal tolerance in Antarctic fish investigated by MRI and ${ }^{31} \mathrm{P}-\mathrm{MRS}$. Am J Physiol, Regul Integr Comp Physiol 283:R1254-R1262

Mark FC, Lucassen M, Pörtner HO (2006b) Thermal sensitivity of uncoupling proteins in polar and temperate fish. Comp Biochem Physiol D1:365-374

Nikinmaa M (2002) Oxygen-dependent cellular functions-why fishes and their aquatic environment are a prime choice of study. Comp Biochem Physiol 133A:1-16

Nikinmaa M, Pursiheimo S, Soitamo AJ (2004) Redox state regulates HIF- $1 \alpha$ and its DNA binding and phosphorylation in salmonid cells. J Cell Sci 117:3201-3206

Nikinmaa M, Rees BB (2005) Oxygen-dependent gene expression in fishes. Am J Physiol Regul Integr Comp Physiol 288R:10791090

Minet E, Mottet D, Michel G, Roland I, Raes M, Remacle J, Michiels C (1999) Hypoxia-induced activation of HIF-1: role of HIF1alpha-Hsp90 interaction. FEBS Lett 460(2):251-256 
Morin PJ, McMullen DC, Storey KB (2005) HIF-1 $\alpha$ involvement in low temperature and anoxia survival by a freeze tolerant insect. Mol Cell Biochem 280:99-106

Philipp E, Brey T, Pörtner H-O, Abele D (2005) Chronological and physiological ageing in a polar and a temperate mud clam. Mech Ageing Dev 126:598-609

Philipp E, Brey T, Heilmayer O, Abele D, Pörtner H-O (2006) Physiological ageing in a polar and a temperate swimming scallop. Mar Ecol Prog Ser 307:187-198

Reed DJ (1990) Glutathione: toxicological implications. Annu Rev Pharmacol Toxicol 30:603-631

Rissanen E, Tranberg HK, Sollid J, Nilsson GE, Nikinmaa M (2006) Temperature regulates hypoxia-inducible factor-1 (HIF-1) in a poikilothermic vertebrate, crucian carp (Carassius carassius). J Exp Biol 209:994-1003

Sartoris FJ, Bock C, Pörtner HO (2003) Temperature-dependent pH regulation in eurythermal and stenothermal marine fish: an interspecies comparison using ${ }^{31} \mathrm{P}-\mathrm{NMR}$. J Therm Biol 28:363-371

Schafer FQ, Buettner GR (2001) Redox environment of the cell as viewed through the redox state of the glutathione disulfide/ glutathione couple. Free Rad Biol Med 30:1191-1212

Shams I, Nevo E, Avivi A (2004) Ontogenetic expression of erythropoietin and hypoxia inducible factor-1 alpha genes in subterranean blind mole rats. FASEB: doi:10.1096/fj.04-2758fje

Soitamo AJ, Rabergh CMI, Gassmann M, Sistonen L, Nikinmaa M (2001) Characterization of a hypoxia-inducible factor (HIF-1 $\alpha$ ) from rainbow trout. J Biol Chem 276:19677-19705
Stroka DM, Burkhardt T, Desbaillets I, Wenger RH, Neil DAH, Gassmann M, Candinas D (2001) HIF-1 is expressed in normoxic tissue and displays an organ-specific regulation under systemic hypoxia. FASEB J 15:2445-2453

Uchiyama M, Mihara M (1978) Determination of malonaldehyde precursor in tissues by thiobarbituric acid test. Anal Biochem 86:271-278

Van Dijk PLM, Tesch C, Hardewig I, Pörtner H-O (1999) Physiological disturbances at critically high temperatures: a comparison between stenothermal antarctic and eurythermal temperate eelpouts (Zoarcidae). J Exp Biol 202:3611-3621

Vegh M, Marton A,Horvath I (1988) Reduction of Fe(III) ADP complex by liver microsomes. Biochim Biophys Act 964:146150

Vuori KAM, Soitamo A, Vuorinen PJ, Nikinmaa M (2004) Baltic salmon (Salmo salar) yolk-sac fry mortality is associated with disturbances in the function of hypoxia-inducible transcription factor (HIF-1 $\alpha$ ) and consecutive gene expression. Aquat Toxicol 68:301-313

Wenger RH (2000) Mammalian oxygen sensing, signalling and gene regulation. J Exp Biol 203:1253-1263

Woodmansee AN, Imlay JA (2002) Meth Enzymol 349:3-9

Yegorov DY, Kozlov AV, Azizova OA, Vladimorov YA (1993) Simultaneous determination of $\mathrm{Fe}$ (III) and $\mathrm{Fe}$ (II) in water solutions and tissue homogenates using desferal and 1,10phenanthroline. Free Rad Biol Med 15:565-574 